\title{
Quality and functional properties of 'Tupy' blackberry stored in modified atmosphere conditions
}

\author{
Cristina Soethe ${ }^{1}$, Cristiano André Steffens ${ }^{2}$, Mariuccia Schlichting de Martin ${ }^{3}$, \\ Cassandro Vidal Talamini do Amarante ${ }^{4}$, Angélica Schmitz Heinzen ${ }^{5}$, Aike Anneliese Kretzschmar ${ }^{6}$ \\ Abstract - The aim of this work was to evaluate the effect of storage temperature, in passive \\ modified atmosphere (MA) and atmospheric composition in active MA on quality maintenance, \\ total phenolic compounds (TPC) and total antioxidant activity (TAA; DPPH and ABTS methods) \\ of 'Tupy' blackberry. Two experiments were carried out. In experiment 1 , the fruit were stored \\ for eight days at 0,5 and $10{ }^{\circ} \mathrm{C}$ in passive MA. In experiment 2, the initial atmospheres of 21.0 \\ $\mathrm{kPaO}_{2}+0.04 \mathrm{kPaCO}$ (passive MA); $9.2 \mathrm{kPa} \mathrm{O}_{2}+9.2 \mathrm{kPa} \mathrm{CO}_{2}$ (active $\mathrm{MA}$ with high $\mathrm{CO}_{2}$ ); 1.4 \\ $\mathrm{kPaO}_{2}+0.04 \mathrm{kPaCO}$ (active $\mathrm{MA}$ with low $\mathrm{O}_{2}$ ); and $1.4 \mathrm{kPa} \mathrm{O}+9.6 \mathrm{kPa} \mathrm{CO}_{2}$ (active MA with \\ low $\mathrm{O}_{2}+$ high $\mathrm{CO}_{2}$ ) were evaluated for eight days at $0{ }^{\circ} \mathrm{C}$. In both experiments, the fruit were \\ packed in Xtend ${ }^{\circledR}$ plastic films. After eight days of storage in passive MA, temperatures of 0 and \\ $5{ }^{\circ} \mathrm{C}$ provided fruit with higher force to compression and titratable acidity (TA) and lower soluble \\ solids/titratable acidity ratio (SS/TA), but with lower values of TPC and TAA (DPPH method) \\ when compared to the temperature of $10^{\circ} \mathrm{C}$. The fruits stored at $0{ }^{\circ} \mathrm{C}$ presented lower values of \\ weight loss and incidence of decay. Blackberries stored for eight days at $0{ }^{\circ} \mathrm{C}$, in active MA with \\ low $\mathrm{O}_{2}$, associated or not with high $\mathrm{CO}_{2}$, presented lower respiration rate and higher values of \\ TPC and TAA (DPPH method), but did not differ in the values of incidence of decay, force to \\ compression, SS, TA, SS/TA ratio and color attributes when compared to active MA with high \\ $\mathrm{CO}_{2}$ and passive MA. \\ Index Terms: Rubus sp., functional food, conservation, cold storage.

\section{Qualidade e propriedades funcionais de amora-preta 'Tupy' armazenada em condições de atmosfera modificada}

Corresponding author: crisoethe@hotmail.com

Received: March 19, 2018 Accepted: June 29, 2018

Copyright: All the contents of this journal, except where otherwise noted, is licensed under a Creative Commons Attribution License.

\section{$(\mathrm{cc}) \mathrm{E} \mathbf{Y}$}

Resumo - O objetivo deste trabalho foi avaliar o efeito da temperatura de armazenamento, em atmosfera modificada (AM) passiva, e da composição atmosférica em AM ativa sobre a manutenção da qualidade, do teor de compostos fenólicos totais (CFT) e da atividade antioxidante total (AAT; métodos DPPH e ABTS) de amoras-preta 'Tupy'. Foram conduzidos dois experimentos. No experimento 1, os frutos foram armazenados durante oito dias, nas temperaturas de $0 ; 5$ e $10{ }^{\circ} \mathrm{C}$, em AM passiva. No experimento 2, foram avaliadas as atmosferas iniciais de $21,0 \mathrm{kPa} \mathrm{O}+0,04 \mathrm{kPa}$ $\mathrm{CO}_{2}$ (AM passiva); 9,2 $\mathrm{kPa} \mathrm{O}_{2}+9,2 \mathrm{kPa} \mathrm{CO}$ (AM ativa com alto $\mathrm{CO}_{2}$ ); $1,4 \mathrm{kPa} \mathrm{O}_{2}+0,04 \mathrm{kPa} \mathrm{CO}$ (AM ativa com baixo $\mathrm{O}_{2}$ ); e $1,4 \mathrm{kPa} \mathrm{O}_{2}+9,6 \mathrm{kPa} \mathrm{CO}_{2}$ (AM ativa com baixo $\mathrm{O}_{2}+$ alto $\mathrm{CO}_{2}$ ), durante oito dias, na temperatura de $0{ }^{\circ} \mathrm{C}$. Em ambos os experimentos, os frutos foram acondicionados em filmes plásticos Xtend ${ }^{\circledR}$. Após oito dias de armazenamento em AM passiva, as temperaturas de 0 e $5^{\circ} \mathrm{C}$ proporcionaram frutos com maiores valores de força para compressão e acidez titulável (AT), e menor relação sólidos solúveis/acidez titulável (SS/AT), porém com menores valores de CFT e AAT (método DPPH) em relação à temperatura de $10{ }^{\circ} \mathrm{C}$. Os frutos armazenados a $0{ }^{\circ} \mathrm{C}$ apresentaram menores valores de perda de massa fresca (PMF) e de incidência de podridões. Amoras armazenadas durante oito dias a $0{ }^{\circ} \mathrm{C}$, em AM ativa com baixo $\mathrm{O}_{2}$, associado ou não com alto $\mathrm{CO}_{2}$, apresentaram menor respiração e maiores valores de CFT e AAT (método DPPH), porém sem diferirem quanto aos valores de incidência de podridão, força para compressão, SS, $\mathrm{AT}$, relação SS/AT e atributos de cor em relação à $\mathrm{AM}$ ativa com alto $\mathrm{CO}_{2}$ e $\mathrm{AM}$ passiva.

Termos para indexação: Rubus sp., alimento funcional, conservação, armazenamento refrigerado.

\footnotetext{
'Agronomist, M.Sc. Doctoral student in Plant Production, CAV/UDESC. Lages - SC, Brazil. E-mail: crisoethe@hotmail.com (ORCID 0000-0002-1828-617X).

${ }^{2}$ Agronomist, D.Sc. Researcher scholar in Productivity from CNPq, Professor in the Department of Agronomy, CAV/UDESC. Lages - SC, Brazil. E-mail: cristiano.steffens@udesc.br

${ }^{3}$ Agronomist, M.Sc. Researcher at Epagri/Estação experimental de Caçador. Caçador - SC, Brazil. Email: mariucciamartin@epagri.sc.gov.br (ORCID 0000-0002-6857-5594). ${ }^{4}$ Agronomist, D.Sc. Researcher scholar in Productivity from CNPq, Professor in the Department of Agronomy, CAV/UDESC. Lages - SC, Brazil. E-mail: cassandro.amarante@udesc.br

${ }^{5}$ Agronomist, M.Sc. Doctoral student in Plant Production, CAV/UDESC. Lages - SC, Brazil. E-mail: angélica_heinzen@hotmail.com

${ }^{6}$ Agronomist, D.Sc. Researcher scholar in Productivity from CNPq, Professor in the Department of Agronomy, CAV/UDESC. Lages - SC, Brazil. E-mail: aike. kretzschmar@udesc.br
} 


\section{Introduction}

The blackberry (Rubus sp.) is a species that has shown considerable growth in recent years in the South of Brazil (ANTUNES et al., 2014). The 'Tupy' blackberry is more widely grown in Brazil (ANTUNES et al., 2014), resulting from the breeding of Uruguay and Comanche cultivars, conducted by Embrapa Clima Temperado in 1982 (JACQUES; ZAMBIAZI, 2011).

Blackberry shows several components that become it a functional fruit, considering that, when consumed regularly, it is beneficial to human health, in addition to its basic nutritional functions (VIZZOTTO et al., 2012). Blackberry has high antioxidant activity, which can be explained by the synergistic effect between the different phenolic compounds found in the fruit (ACOSTAMONTOYA et al., 2010; SOETHE et al., 2016). These compounds act as antioxidants, due to their oxidationreduction properties, which can play an important role in absorbing and neutralizing the free radicals (SHARMA; SINGH, 2013).

Blackberry is a highly perishable fruit, because of its fragile structure and high respiratory activity (SCHAKER; ANTONIOLLI, 2009). Cold storage at 0 ${ }^{\circ} \mathrm{C}$ does not maintain the content of bioactive compounds effectively and has negative effects on antioxidant activity (SOETHE et al., 2016), requiring other techniques along with it to extend the postharvest shelf life and maintain the quality of blackberries after storage (ANTUNES et al., 2014). Therefore, the cooling combined with the use of plastic package can extend the storage period of the fruit for reducing its respiration. According to Schaker and Antoniolli (2009), the cold storage associated with modified atmosphere (MA) can be an additional technique for maintaining the fruit quality. The ideal storage temperature for black berry is between 0 and 5 ${ }^{\circ} \mathrm{C}$ (WANG; WANG, 2009), and, at the temperature of 0 ${ }^{\circ} \mathrm{C}$, it can be retained for two to three days without loss of fruit quality (JOO et al., 2011). However, blackberry from Brazos cultivar shows satisfactory quality after nine days of MA storage at $2{ }^{\circ} \mathrm{C}$ and $5{ }^{\circ} \mathrm{C}$ (PALHARINI et al., 2015).

In addition to cooling, the MA obtained from the use of plastic films promotes the reduction in respiration by decreasing the $\mathrm{O}_{2}$ levels and increasing $\mathrm{CO}_{2}$ levels, contributing, thus, to delaying the senescence of fruits (SANDHYA, 2010). $\mathrm{O}_{2}$ levels from 5 to $10 \mathrm{kPa}$ and $\mathrm{CO}_{2}$ levels from 15 to $20 \mathrm{kPa}$ have been indicated for reduction in the respiration rate and the loss of firmness of blackberries and prolongation of their shelf life (MITCHAM et al., 2007).

This study aimed to evaluate the effect of the storage temperature in the passive MA and of the atmospheric composition in the active MA on the maintenance of the quality, the content of phenolic compounds and the antioxidant activity of 'Tupy' blackberry.

\section{Material and methods}

The experiment was conducted in 2014, with 'Tupy' blackberry from an experimental orchard located in the municipality of Lages, SC (located at latitude $27^{\circ} 48^{\prime} 58^{\prime \prime} \mathrm{S}$, longitude $50^{\circ} 19^{\prime} 34^{\prime \prime} \mathrm{W}$, altitude of $884 \mathrm{~m}$ ). The blackberries were harvested in mature stage (glossy black), in the morning and placed directly into polyethylene terephthalate trays (PET) without lid (40 fruits per tray). After harvesting, the fruits were weighed and kept at $2{ }^{\circ} \mathrm{C}$ until the next morning, when the experiments occurred.

With this harvest, two experiments were conducted. In the first experiment, the storage temperatures of 0,5 and $10{ }^{\circ} \mathrm{C}\left( \pm 0.2{ }^{\circ} \mathrm{C}\right.$ and $\left.92 \pm 5 \% \mathrm{RH}\right)$ were evaluated with fruits stored in passive MA. In the second experiment, the initial atmospheres of $21.0 \mathrm{kPa}$ of $\mathrm{O}_{2}+0.04 \mathrm{kPa}$ of $\mathrm{CO}_{2}$ (passive MA) were evaluated; $9.2 \mathrm{kPaO}_{2}+9.2 \mathrm{kPa}$ of $\mathrm{CO}_{2}$ (active MA with high $\mathrm{CO}_{2}$ ); $1.4 \mathrm{kPa} \mathrm{O}_{2}+0.04 \mathrm{kPa}$ of $\mathrm{CO}_{2}$ (active $\mathrm{MA}$ with low $\mathrm{O}_{2}$ ); and $1.4 \mathrm{kPa} \mathrm{O}_{2}+9.6 \mathrm{kPa}$ of $\mathrm{CO}_{2}$ (active MA with low $\mathrm{O}_{2}+$ high $\mathrm{CO}_{2}$ ), at $0 \pm 0.2{ }^{\circ} \mathrm{C}$. Trays containing the fruits of both experiments were placed in cardboard boxes without lids, fit for blackberry, and the fruits were wrapped in plastic films Xtend ${ }^{\circledR}$ 815-BL2, produced by StePac L.A. Ltd., Israel, with a capacity of $1.5 \mathrm{~kg}$ of fruit.

The partial pressures of the gases were obtained from the dilution of $\mathrm{O}_{2}$, inside the package, with injection of $\mathrm{N}_{2}$ from a nitrogen generator that uses the principle "Pressure Swing Adsorption" (PSA), and the high $\mathrm{CO}_{2}$ treatments were obtained from the injection of $\mathrm{CO}_{2}$, from high-pressure cylinders, until it reached the level established. In the treatment with low $\mathrm{O}_{2}$ only, hydrated lime wrapped in paper was placed inside the packages to absorb the $\mathrm{CO}_{2}$ from the respiration process for isolation of the effect of MA with low initial $\mathrm{O}_{2}$. The monitoring of the partial pressures of gases, ranging due to the respiration of the fruits and the plastic film permeability, was performed at $0,1,4$ and 8 days of storage, using a gas analyzer $\left(\mathrm{O}_{2}+\mathrm{CO}_{2}\right)$, Schelle ${ }^{\circledR}$ (Kronenberger/ Climasul, Caxias do Sul, Brazil).

After eight days of storage, the fruits were exposed to room temperature $\left(20^{\circ} \mathrm{C}\right)$ for 4 hours, until regulating their temperature, and assessed regarding their respiration rate, fresh weight loss (FWL), incidence of rotting, compressive strength, titratable acidity (TA), soluble solids (SS), SS/TA ratio, epidermis color, total phenolic compounds (TPC) and total antioxidant activity (TAA; DPPH and ABTS assays).

The respiration rate $\left(\mu \mathrm{mol} \mathrm{CO} \mathrm{Cg}^{-1} \mathrm{~s}^{-1}\right)$ was quantified by putting 40 fruits of each sample in a 480 $\mathrm{mL}$ container, hermetically sealed. After 60 minutes, using $1 \mathrm{~mL}$ syringes, the internal atmosphere of the container was sampled and $\mathrm{CO}_{2}$ concentrations were measured, using a Varian ${ }^{\circledR}$ CP-3800 gas chromatograph (Palo Alto, CA, USA), equipped with a $3 \mathrm{~m}$ Porapak $\mathrm{N}^{\circledR}$ column, 
methanation reactor and flame ionization detector.

The epidermis color was evaluated regarding the values of lightness (L), chroma (C) and hue (h) using a Minolta ${ }^{\circledR}$ CR 400 colorimeter (Konica, Tokyo, Japan). The readings were held in two opposite points of the equatorial region of the fruits. The values of $L$ ranged from 0 (black) to 100 (white). Thus, the higher the values of $\mathrm{L}$, the darker would be the color of the fruits. The values of $\mathrm{C}$ are related to the color purity (on a scale from 0 to 100). The values of $h$ correspond to the colors of the surface of vegetable tissue as follows: $0^{\circ} \mathrm{red} /, 90^{\circ} /$ yellow, $180^{\circ}$ / green and $270^{\circ}$ /blue.

The compressive strength of fruits (texture) was analyzed with a TAXT-Plus ${ }^{\circledR}$ electronic texture analizer (Stable Micro Systems Ltd, Surrey, United Kingdom). A lifting platform, model $\mathrm{P} / 75$ with $75 \mathrm{~mm}$ in diameter, which exerted a compressive strength until a $3 \mathrm{~mm}$ deformation on the fruit surface, was used.

The values of TA ( $\%$ citric acid) were obtained from a sample of $10 \mathrm{~mL}$ juice, obtained by processing the fruits in a centrifuge. This sample was diluted in 90 $\mathrm{mL}$ of distilled water and titrated with a $0.1 \mathrm{~N} \mathrm{NaOH}$ solution until the $\mathrm{pH}$ 8.1. For titration, a TitroLine Easy ${ }^{\circledR}$ automatic titrator (Schott Instruments, Mainz, RheinlandPfalz, Germany) was used. The SS contents (\%) were determined in a PR201 $\alpha$ digital refractometer (Atago ${ }^{\circledR}$, Tokyo, Japan), using an aliquot of the juice obtained by processing the fruit.

The incidence of rotting was evaluated by counting the fruits affected that showed external lesions with characteristics of infection by pathogens. Results were expressed in percentage (\%). To evaluate FWL, the fruits were weighed on an analytical balance, and the FWL evaluated considering the difference of their weight between the harvest and removal of the storage chamber, and the values expressed in percentage (\%).

For obtaining blackberry extracts, used for quantifying total phenolic compounds and total antioxidant activity, $5 \mathrm{~g}$ of the sample, which was homogenized with $10 \mathrm{~mL}$ acidified ethanol $(0.01 \% \mathrm{HCl})$, followed by centrifugation at $4{ }^{\circ} \mathrm{C}$ for 5 minutes at $15000 \mathrm{rpm}$, was used. After filtering, the supernatant was reserved for analysis of TCP and TAA.

The determination of TCP was performed using the Folin-Ciocalteau reagent. The standard curve was obtained using gallic acid, at concentrations of $0,10,30,50,70,90$ and $100 \mathrm{ppm}$. For analysis, $2.5 \mathrm{~mL}$ Folin-Ciocalteau (1:3), $0.5 \mathrm{~mL}$ of sample and $2.0 \mathrm{~mL}$ sodium carbonate solution $10 \%$ were added. The tubes were shaken and incubated for 1 hour in the dark. The reading was performed at the wavelength of $765 \mathrm{~nm}$ in UV-visible spectrophotometer (HITACHI, model U-1100, Japan). The results were expressed in $\mathrm{mg}$ of gallic acid equivalent (GAE) per 100 $\mathrm{g}$ fresh weight (mg GAE $100 \mathrm{~g}^{-1} \mathrm{FW}$ ).

The determination of TAA was based on the extinction of the absorbance of the radicals DPPH (2.2-difenil-1-picril hidrazil) and ABTS (2.2-azinobis3-etilbenzotiazolin-6-sulfonic acid). The DPPH assay was analyzed according to Vizzotto et al. (2012). In dark environment, $200 \mu \mathrm{L}$ of sample was pipetted and mixed with $3.800 \mu \mathrm{L}$ of DPPH. The tubes were shaken and left to react for 24 hours. The reading was performed at $\lambda=525$ $\mathrm{nm}$, and the results expressed in $\mu \mathrm{g}$ of Trolox equivalent $\mathrm{g}^{-1}$ FW. The ABTS assay was analyzed as described by Rufino et al. (2007), with adaptations. In dark environment, 30 $\mu \mathrm{L}$ of sample was pipetted and mixed with $3.000 \mu \mathrm{L}$ of DPPH. The reading was performed after a 6-minute reaction at $\lambda=734 \mathrm{~nm}$, and the results expressed in $\mu \mathrm{g}$ of Trolox equivalent $\mathrm{g}^{-1} \mathrm{FW}$.

For both experiments, the completely randomized design was the experimental design used, with five replications per treatment, and the experimental unit consisted of 40 fruits. For statistical analysis, data were subjected to analysis of variance (ANOVA), and data from incidence of rotting were transformed by the arc sine formula $[(\mathrm{x}+1) / 100]^{1 / 2}$ before being submitted to ANOVA. For comparison of the averages, the Tukey test $(p<0.05)$ was used. For these procedures, the SAS statistical software (SAS Institute, Cary, USA) was used.

\section{Results and discussion}

At harvest, the 'Tupy' blackberries, used in both experiments showed SS of $8.63 \%$; TA of $1.40 \%$ citric acid; SS/TA ratio of $6.25 ; L^{*}$ of $13.3 ; C$ of $2.08 ; h^{\circ}$ of 73.2 ; compressive strength of the fruit of $4.34 \mathrm{~N}$; TCP of $229.7 \mathrm{mg} \mathrm{GAE} 100 \mathrm{~g}^{-1} \mathrm{FW}$; and TAA of $9373.5 \mu \mathrm{g}$ of eq. Trolox g ${ }^{-1} \mathrm{FW}$ and $32.2 \mu \mathrm{g}$ of eq. Trolox $\mathrm{g}^{-1} \mathrm{FW}$, for DPPH and ABTS assays, respectively.

The increase in temperature caused considerable changes in the partial pressures of $\mathrm{O}_{2}$ and $\mathrm{CO}_{2}$ inside the packages during the storage period. The reduction in partial pressure of $\mathrm{O}_{2}$ and the increase in $\mathrm{CO}_{2}$ partial pressure inside the packages was greater with temperature increase from 5 to $10{ }^{\circ} \mathrm{C}$ than from 0 to $5{ }^{\circ} \mathrm{C}$, especially from four days of storage on. At the end of the storage period, the partial pressures inside the packaging were $17.6 \mathrm{kPa} \mathrm{O}$ $+2.3 \mathrm{kPaCO}_{2} ; 15.3 \mathrm{kPaO}_{2}+5.0 \mathrm{kPa} \mathrm{CO} ; 7.1 \mathrm{kPaO}_{2}+$ $13.5 \mathrm{kPa} \mathrm{CO}$ for 0,5 and $10^{\circ} \mathrm{C}$, respectively (Figures $1 \mathrm{~A}$ and $1 \mathrm{~B}$ ). The ability to regulate the atmosphere established on the package will depend on the fruit respiration and on the package permeability (VIEITES et al., 2006), which in turn depends on the temperature (STEFFENS et al., 2009), since its elevation increases the permeability of the film used and the respiration rate (STEFFENS et al., 2007), causing changes in the gas concentration inside the package, by $\mathrm{O}_{2}$ consumption and $\mathrm{CO}_{2}$ release.

Respiration rate in the fruits stored at $10{ }^{\circ} \mathrm{C}$ was higher than that of the fruits stored at 0 and $5^{\circ} \mathrm{C}$ (Table 1 ), 
which may explain the difference in partial pressures of $\mathrm{O}_{2}$ and $\mathrm{CO}_{2}$ on the packs. The use of a $\mathrm{CO}_{2}$ partial pressure higher than the atmospheric pressure slightly inhibits fruit respiration. However, its efficiency is combined with low temperatures, because the temperature is the main factor influencing the respiration rate (STEFFENS et al., 2007). According to Sandhya et al. (2010), cooling is necessary as a measure for controlling fruit respiration and transpiration during storage by reducing the respiration rates and delaying the ripening.

The reduction in temperature caused minor FWL of the fruits (Table 1). The reduction in FWL in fruits is directly related to the deficit of water vapor pressure between the fruit and the atmosphere, which increases as storage temperature increases (DAMIANI et al., 2008). However, despite FWL increased in higher storage temperature, the values obtained in this study were lower even in the fruits stored at $10^{\circ} \mathrm{C}$, not affecting the visual quality due to withering of fruits. The low FWL observed may be related to high humidity inside the package, since the fruits were packed in polyethylene terephthalate trays and wrapped with Xtend ${ }^{\circledR}$ flexible films.

The incidence of rotting was lower in the fruits stored at $0{ }^{\circ} \mathrm{C}$, but they showed no differences compared with those stored at $5^{\circ} \mathrm{C}$ (Table 1). Palharini et al. (2015) also observed a lower incidence of rotting in blackberries stored in lower temperatures. The highest incidence of rotting observed at $10{ }^{\circ} \mathrm{C}$ may be related to high temperature combined with high relative humidity inside the package (CIA et al., 2007). However, the values of incidence of rotting found in this study were lower than those found in 'Tupy' blackberries stored at the same temperatures, but without MA (SOETHE et al., 2016). According to Vieites et al. (2006), the MA caused by fruits inside of polymeric films can reduce the incidence of rotting, but it is more efficient when associated with lower temperatures, as observed at 0 and $5^{\circ} \mathrm{C}$ (Table 1 ), because the increased $\mathrm{CO}_{2}$ concentrations inside the package may reduce the incidence of rotting (WEBER et al., 2013).

'Tupy' blackberries stored at $10^{\circ} \mathrm{C}$ showed reduced compressive strength compared with those stored at 0 and $5{ }^{\circ} \mathrm{C}$ (Table 1). According to Souza et al. (2006), at higher temperatures, enzyme activity increases due to cell-wall degradation, such as polygalacturonase and pectin methylesterase, reducing the fruit firmness. The blackberries stored at $10{ }^{\circ} \mathrm{C}$ were less firm probably due to their lower turgidity, because a higher FWL occurred in this condition.

Regarding the contents of SS, no differences were found between the storage temperatures (Table 2). The lack of effect of temperature on the values of SS in MA is probably due to the delayed ripening and the senescence of the fruits, caused by a major atmospheric change inside the package.

For TA, the lowest values were obtained at $10{ }^{\circ} \mathrm{C}$
(Table 2), due to the increased respiratory activity in fruits at this temperature (Table 1). As the storage temperature increases, degradative enzymatic processes are intensified, resulting in a greater consumption of organic acids, used as respiratory substrates (STEFFENS et al., 2007). The value of the SS/TA ratio was higher in fruits stored at 10 ${ }^{\circ} \mathrm{C}$ (Table 2), which is explained by a lower TA of the fruits stored at this temperature.

No difference was observed between the storage temperatures regarding the epidermis color attributes (Table 2). Soethe et al. (2016) also did not observe differences between the storage temperatures regarding the epidermis color in 'Tupy' blackberries. However, according to Bischoff et al. (2013), cranberries wrapped in MA have their color changed more slowly compared with the fruits without package.

The TCP content was higher in the blackberries stored at $10{ }^{\circ} \mathrm{C}$ than in those stored at 0 and $5{ }^{\circ} \mathrm{C}$ (Table 3). Similar results were reported by Kivi et al. (2014) for raspberries. The increased TCP content at $10^{\circ} \mathrm{C}$ can, partially, be associated with higher FWL of the fruits at this temperature (Table 1). According to Bhat and Stamminger (2016), the cause of the increased TCP content may be the release of conjugated phenolic compounds present in the cell wall and the activation of the phenylalanineammonia-lyase (PAL) enzyme. On the other hand, at lower temperatures $\left(0\right.$ and $\left.5^{\circ} \mathrm{C}\right)$ production of reactive oxygen species may occur, resulting in greater consumption of phenolic compounds and reducing the concentration of these compounds in the fruit (JUNMATONG et al., 2015). In addition, according to Bhat and Stamminger (2016), lower storage temperature can decrease the enzymatic activity, contributing to the reduction of TCP content in the fruit.

No difference was observed for TAA, by the ABTS assay, between the storage conditions evaluated. For the DPPH assay, TAA content was higher in the blackberries stored at $10^{\circ} \mathrm{C}$ than in those stored at 0 and $5^{\circ} \mathrm{C}$ (Table 3 ).

The storage at $10^{\circ} \mathrm{C}$ slightly increased TCP and TAA contents. However, this storage condition provided greater FWL and incidence of rotting, affecting the fruit appearance. In addition, it reduced the TA and the compressive strength, affecting sensory characteristics related to palatability. Thus, despite the positive effect of the storage at $10{ }^{\circ} \mathrm{C}$ on the TCP content and TAA, this storage condition is unfeasible due to the impairment of the quality of the fruits.

Table 4 shows the values of partial pressures of $\mathrm{O}_{2}$ and $\mathrm{CO}_{2}$ inside the package at the beginning of the experiment 2 and after 8 days of storage.

The active MA with low $\mathrm{O}_{2}$, combined or not with high $\mathrm{CO}_{2}$, reduced respiration rate (Table 5) and increased the values of TCP and TAA (measured by the DPPH assay, but not by the ABTS assay) (Table 7), when compared with active MA with high $\mathrm{CO}_{2}$ and passive MA. 
In general, low partial pressures of $\mathrm{O}_{2}$ associated with high partial pressures of $\mathrm{CO}_{2}$, since they are not excessive to the extent of inducing fermentation, cause larger reductions in the respiration rate of the fruit than the separate action of the same values, low of $\mathrm{O}_{2}$ or high of $\mathrm{CO}_{2}$ (CIA et al., 2007; SANDHYA, 2010). Nonetheless, as the $\mathrm{CO}_{2}$ levels inside the package were very similar in all treatments, with values that are not very high at the end of the experiment (between 2 and $3 \mathrm{kPa}$ ), the most obvious effect was that of MA with low $\mathrm{O}_{2}$ on the reduction of respiratory rate and increase in the values of TCP and TAA. However, this effect of low $\mathrm{O}_{2}$ must be the result of partial pressures at the beginning of the storage, considering that values increased to $15.5-16.5$ $\mathrm{kPa}$ at the end of the storage, in treatments of low $\mathrm{O}_{2}$ active MA, combined or not with high $\mathrm{CO}_{2}$. Therefore, these treatments did not differ from high $\mathrm{CO}_{2}$ active MA and passive MA concerning the values of incidence of rotting, compressive strength, SS, TA, SS/TA ratio and color attributes (Tables 5 and 6).

No difference was observed between active and passive MA for FWL in 'Tupy' blackberries (Table 5). The low FWL when using package is related to the film water vapor permeability rate and to the effect of storage temperature. The lower the transmission rate, the lower the deficit of water vapor pressure and the higher the relative humidity inside the package, thus reducing the transpiration of the fruits (CIA et al., 2007). The deficit of vapor pressure between the fruit and the air of the atmosphere at the storage environment must have been similar between treatments, once the blackberries were stored at the same temperature and package.

The incidence of rotting are not different between the modified atmospheres evaluated (Table 5). The low $\mathrm{O}_{2}$ and $\mathrm{CO}_{2}$ concentrations may reduce respiration rates, oxidation and deterioration of the fruits (SANDHYA, 2010), thereby reducing their susceptibility to the occurrence of rotting. Considering that the storage conditions evaluated provided similar texture (compressive strength; Table 5) in this study, the fruits possibly showed a resistance similar to infection by pathogens, as well as the effect of storage temperature $\left(0^{\circ} \mathrm{C}\right)$. Soethe et al. (2016) observed lower incidence of rotting in blackberries stored at $0{ }^{\circ} \mathrm{C}$. Furthermore, the increased $\mathrm{CO}_{2}$ levels may have been insufficient to reduce the incidence of rotting, since all the conditions showed partial pressures of $\mathrm{CO}_{2}$ below 3.0 $\mathrm{kPa}$ at the end of the storage period.

No differences were found between the MA evaluated for compressive strength (Table 5), SS content, TA, SS/TA ratio and color attributes of the epidermis of 'Tupy' blackberry (Table 6). According to Cia et al. (2007), the decrease in $\mathrm{O}_{2}$ levels and increase in $\mathrm{CO}_{2}$ inside the package reduce the respiratory rate and, consequently, the metabolic reactions, delaying the ripening and senescence of fruits.
Blackberries stored in low $\mathrm{O}_{2}$ active $\mathrm{MA}$ and in MA with low $\mathrm{O}_{2}$ and high $\mathrm{CO}_{2}$ showed higher TCP levels than the fruits wrapped in other conditions of MA (Table 7). According to Odriozola-Serrano et al. (2008), the stress induced by inappropriate conditions, such as low $\mathrm{O}_{2}$ levels and high $\mathrm{CO}_{2}$ levels inside the package during storage, can increase the activity of phenylalanine ammonia-lyase (PAL), a key enzyme for the synthesis of phenolic compounds. On the other hand, higher oxygen concentrations may favor the oxidative processes of the main antioxidant compounds, including the phenolic compounds (YANG et al., 2011), reducing their concentration in fruits.

No difference was observed for TAA, by the ABTS assay, between the atmospheric modifications evaluated. For the DPPH assay, blackberries stored in low $\mathrm{O}_{2}$ active MA showed higher TAA than those stored in passive MA or in high $\mathrm{CO}_{2} \mathrm{MA}$, but they showed no differences when compared with blackberries stored in active MA with low $\mathrm{O}_{2}$ and high $\mathrm{CO}_{2}$ (Table 7). Krupa and Tomala (2007) also observed greater antioxidant activity in 'Bluecrop' blueberry stored at low oxygen concentrations ( $1.5 \mathrm{kPa})$. According to Vizzotto et al. (2012), the antioxidant activity in these fruits occurs because of the action of a various phytochemicals that are degraded or synthesized by the fruits, such as vitamins and anthocyanins.

Despite the contribution of the conditions of low $\mathrm{O}_{2}$ active MA, combined or not with high $\mathrm{CO}_{2}$, to the reduction in the respiration rate and to the preservation of TCP and TAA, the reduction in metabolism was not enough to provide differences in diseases, color, pulp firmness, SS content and TA of the fruits. However, the storage of 'Tupy' blackberries in these conditions can provide major benefits to human health, because it results in fruits with higher TCP and TAA values. 

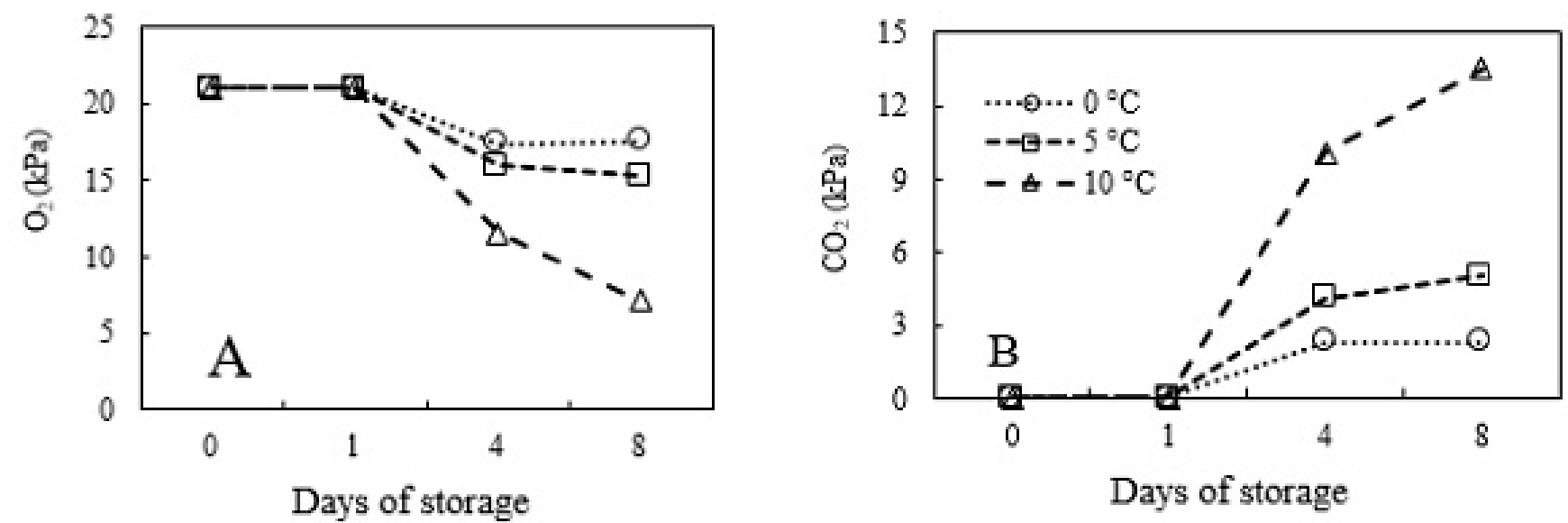

Figure 1. Partial pressures of $\mathrm{O}_{2}$ (Figure A) and $\mathrm{CO}_{2}$ (Figure B) inside the storage packages of 'Tupy' blackberries maintained at different temperatures.

Table 1. Respiratory rate ( $\mu \mathrm{mol} \mathrm{CO} \mathrm{kg}^{-1} \mathrm{~s}^{-1}$ ), fresh weight loss (FWL; \%), incidence of rotting (\%) and compressive strength $(\mathrm{N})$ of 'Tupy' blackberry stored in passive modified atmosphere, after eight days, at different temperatures.

\begin{tabular}{lcccc}
\hline Temperature $\left({ }^{\circ} \mathrm{C}\right)$ & Respiratory rate & FWL & Incidence of rotting & Compressive strength \\
\hline 0 & $0.93 \mathrm{~b}^{*}$ & $1.79 \mathrm{c}$ & $15.74 \mathrm{~b}$ & $3.99 \mathrm{a}$ \\
5 & $1.01 \mathrm{~b}$ & $2.72 \mathrm{~b}$ & $16.42 \mathrm{ab}$ & $4.07 \mathrm{a}$ \\
10 & $2.10 \mathrm{a}$ & $3.21 \mathrm{a}$ & $21.29 \mathrm{a}$ & $3.23 \mathrm{~b}$ \\
\hline $\mathrm{CV}(\%)$ & 9.43 & 4.59 & 9.16 & 8.94 \\
\hline
\end{tabular}

"Means followed by a different letter in the column are statistically different by Tukey test $(\mathrm{p}<0.05)$.

Table 2. Soluble solids (SS; \%), titratable acidity (TA; \% citric acid), SS/TA ratio and color attributes (lightness -

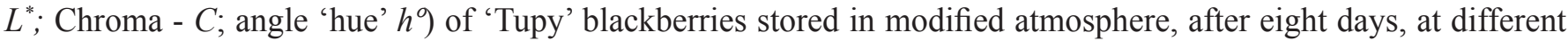
temperatures.

\begin{tabular}{lcccccc}
\hline \multirow{2}{*}{ Temperature $\left({ }^{\circ} \mathrm{C}\right)$} & \multirow{2}{*}{$\mathrm{SS}$} & \multirow{2}{*}{$\mathrm{TA}$} & \multirow{2}{*}{$\mathrm{SS} / \mathrm{TA}$} & \multicolumn{3}{c}{ Color attributes } \\
\cline { 6 - 8 } & & & & $L^{*}$ & $C$ & $h^{\circ}$ \\
\hline 0 & $8.9^{\text {ns }}$ & $1.12 \mathrm{a}^{*}$ & $7.94 \mathrm{~b}$ & $15.63^{\text {ns }}$ & $2.11^{\text {ns }}$ & $60.20^{\text {ns }}$ \\
5 & 8.5 & $1.12 \mathrm{a}$ & $7.59 \mathrm{~b}$ & 15.83 & 2.01 & 59.93 \\
10 & 8.5 & $0.94 \mathrm{~b}$ & $9.34 \mathrm{a}$ & 15.35 & 1.92 & 59.79 \\
\hline $\mathrm{CV}(\%)$ & 8.35 & 6.26 & 9.46 & 2.70 & 12.31 & 4.11 \\
\hline
\end{tabular}

"Means followed by a different letter in the column are statistically different by Tukey test $(\mathrm{p}<0.05)$. ns= no significant differences.

Table 3. Total phenolic compounds (TCP; mg GAE $100 \mathrm{~g}^{-1} \mathrm{FW}$ ) and total antioxidant activity (TAA; quantified by the DPPH and ABTS assays, expressed as $\mu$ g of Trolox equivalent $\left.\mathrm{g}^{-1} \mathrm{FW}\right)$, 'Tupy' blackberry stored in modified atmosphere, after eight days, at different temperatures.

\begin{tabular}{lccc}
\hline \multirow{2}{*}{ Temperature $\left({ }^{\circ} \mathrm{C}\right)$} & \multirow{2}{*}{ TCP } & DPPH & TAA \\
\cline { 3 - 4 } & & $8519.6 \mathrm{~b}$ & $29.4^{\mathrm{ns}}$ \\
\hline 0 & $147.5 \mathrm{~b}^{*}$ & $8395.8 \mathrm{~b}$ & 30.8 \\
5 & $148.2 \mathrm{~b}$ & $9876.4 \mathrm{a}$ & 31.1 \\
\hline $\mathrm{CV}(\%)$ & $238.8 \mathrm{a}$ & 3.64 & 7.36 \\
\hline
\end{tabular}

*Means followed by a different letter in the column are statistically different by Tukey test $(\mathrm{p}<0.05)$. ns $=$ no significant differences. 
Table 4. Shows the values of partial pressures $\mathrm{O}_{2}(\mathrm{kPa})$ and $\mathrm{CO}_{2}(\mathrm{kPa})$ inside the package at the beginning of the experiment and after 8 days of storage in modified atmosphere (AM; $0 \pm 0.2{ }^{\circ} \mathrm{C}$ and $92 \pm 5 \%$ of $\mathrm{RH}$ ).

Postharvest treatments

$\mathrm{O}_{2} \quad \mathrm{CO}_{2}$

At the beginning of the experiment

Passive MA

$21.0 \quad 0.04$

Active MA with high $\mathrm{CO}_{2}$

$9.2 \quad 9.2$

Active MA with low $\mathrm{O}_{2}$

1.10 .04

Active MA with low $\mathrm{O}_{2}$ and high $\mathrm{CO}_{2}$

1.4

Passive MA

After eight days of storage

Active MA with high $\mathrm{CO}_{2}$

17.62 .3

Active MA with low $\mathrm{O}_{2}$

$18.3 \quad 2.2$

Active MA with low $\mathrm{O}_{2}$ and high $\mathrm{CO}_{2}$

15.3

2.2

16.4

2.9

Table 5. Respiration rate ( $\left.\mu \mathrm{mol} \mathrm{CO} \mathrm{kg}^{-1} \mathrm{~s}^{-1}\right)$, fresh weight loss (FWL, \%), incidence of rotting (\%) and compressive strength $(\mathrm{N})$ of 'Tupy' blackberry after storage for eight days at $0{ }^{\circ} \mathrm{C}$ in different MAs.

\begin{tabular}{lcccc}
\hline Postharvest treatments & Respiration rate & FWL & $\begin{array}{c}\text { Incidence of } \\
\text { rotting }\end{array}$ & $\begin{array}{c}\text { Compressive } \\
\text { strength }\end{array}$ \\
\hline Passive MA & $0.93 \mathrm{a}^{*}$ & $1.79^{\text {ns }}$ & $15.7^{\text {ns }}$ & $3.99^{\text {ns }}$ \\
Active MA with high $\mathrm{CO}_{2}$ & $0.89 \mathrm{a}$ & 1.77 & 17.5 & 3.69 \\
Active MA with low $\mathrm{O}_{2}$ & $0.71 \mathrm{~b}$ & 1.77 & 17.0 & 3.97 \\
Active MA with low $\mathrm{O}_{2}$ and high $\mathrm{CO}_{2}$ & $0.71 \mathrm{~b}$ & 1.93 & 12.8 & 3.47 \\
\hline $\mathrm{CV}(\%)$ & 6.9 & 3.7 & 16.7 & 13.3 \\
\hline
\end{tabular}

*Means followed by a different letter in the column are statistically different by Tukey test $(\mathrm{p}<0.05)$. MA=modified atmosphere; ns= no significant differences.

Table 6. Soluble solids (SS; \%), titratable acidity (TA; \% citric acid), SS/TA ratio and color attributes (lightness $-L^{*}$; Chroma - $C$; angle 'hue' $-h^{\circ}$ ) of 'Tupy' blackberries after storage for eight days at $0{ }^{\circ} \mathrm{C}$ in different MAs.

\begin{tabular}{lcccccc}
\hline Postharvest treatments & $\mathrm{SS}$ & $\mathrm{TA}$ & $\mathrm{SS} / \mathrm{TA}$ & $L^{*}$ & $C$ & $h^{\circ}$ \\
\hline Passive MA & $8.9^{\mathrm{ns}}$ & $1.12^{\mathrm{ns}}$ & $7.94^{\mathrm{ns}}$ & $15.63^{\text {ns }}$ & $2.11^{\mathrm{ns}}$ & $60.20^{\text {ns }}$ \\
Active MA with high $\mathrm{CO}_{2}$ & 9.2 & 1.09 & 8.44 & 15.06 & 2.01 & 64.97 \\
Active MA with low $\mathrm{O}_{2}$ & 9.2 & 1.04 & 8.84 & 15.22 & 1.96 & 60.96 \\
Active MA with low $\mathrm{O}_{2}$ and high $\mathrm{CO}_{2}$ & 8.7 & 1.22 & 7.13 & 15.39 & 2.09 & 62.55 \\
\hline CV $(\%)$ & 6.96 & 10.24 & 14.81 & 3.17 & 13.57 & 4.55 \\
\hline
\end{tabular}

$\mathrm{MA}=$ modified atmosphere; $\mathrm{ns}=$ no significant differences by Tukey test $(\mathrm{p}<0.05)$.

Table 7. Total phenolic compounds (TCP; mg GAE $100 \mathrm{~g}^{-1}$ ) and total antioxidant activity (TAA; quantified by the DPPH and ABTS assays, expressed as $\mu \mathrm{g}$ of Trolox equivalent $\mathrm{g}^{-1}$ of fresh weight), of 'Tupy' blackberry stored in modified atmosphere, after storage for eight days at $0{ }^{\circ} \mathrm{C}$ in different MAs.

\begin{tabular}{lccc}
\hline \multirow{2}{*}{ Postharvest treatments } & \multirow{2}{*}{ TCP } & DPPH & ABTS \\
\cline { 3 - 4 } Passive MA & $147.46 \mathrm{~b}^{*}$ & $8519.6 \mathrm{~b}$ & $29.36^{\text {ns }}$ \\
Active MA with high $\mathrm{CO}_{2}$ & $169.06 \mathrm{~b}$ & $7959.6 \mathrm{~b}$ & 28.19 \\
Active MA with low $\mathrm{O}_{2}$ & $209.02 \mathrm{a}$ & $10584.5 \mathrm{a}$ & 33.50 \\
Active MA with low $\mathrm{O}_{2}$ and high $\mathrm{CO}_{2}$ & $202.58 \mathrm{a}$ & $9241.6 \mathrm{ab}$ & 31.32 \\
\hline $\mathrm{CV}(\%)$ & 7.28 & 8.70 & 11.83 \\
\hline
\end{tabular}

"Means followed by a different letter in the column are statistically different by Tukey test $(\mathrm{p}<0.05)$. MA=modified atmosphere; ns= no significant differences. 


\section{Conclusions}

The storage of 'Tupy' blackberry for eight days at 0 and $5{ }^{\circ} \mathrm{C}$ in a passive modified atmosphere maintains the physicochemical quality of the fruit. The storage at 10 ${ }^{\circ} \mathrm{C}$ does not maintain the quality of the fruit satisfactorily, but provides higher levels of total phenolic compounds and total antioxidant activity.

The storage of 'Tupy' blackberries for eight days at $0{ }^{\circ} \mathrm{C}$ in low $\mathrm{O}_{2}$ modified atmosphere, associated or not with high $\mathrm{CO}_{2}$, provides lower respiration activity and higher values of total phenolic compounds and total antioxidant activity (DPPH assay), but does not interfere with the maintenance of the physicochemical quality and the appearance of the fruits in passive modified atmosphere and active modified atmosphere with high $\mathrm{CO}_{2}$.

\section{Referências}

ACOSTA-MONTOYA, O.; VAILLANT; F.; COZZANO, S.; MERTZ, C.; PÉREZ, A.M.; CASTRO, M.V. Phenolic content and antioxidant capacity of tropical highland blackberry (Rubus adenotrichus Schltdl.) during three edible maturity stages. Food Chemistry, Amsterdam, v.119, n.4, p.1497-1501, 2010.

ANTUNES, L.E.; PEREIRA, I.S.; PICOLOTTO, L.; VIGNOLO, G.K.; GONÇALVES, M.A. PRodução de amoreira-preta no Brasil. Revista Brasileira de Fruticultura, Jaboticabal, v.36, n.1, p.100-111, 2014.

BHAT, R; STAMMINGER, R. Impact of combination treatments of modified Atmosphere packaging and refrigeration on The status of antioxidants in highly perishable strawberries. Journal of Food Process Engineering, Amsterdam, v.39, p.121-131, 2016.

BISCHOFF, T.Z.; PINTRO, T.C.; PALOSCHI, C.L.; COELHO, S.R.M.; GRZEGOZEWSKI, D.M. Conservação pós-colheita da amora-preta refrigerada utilizando biofilme e embalagem plástica. Revista Energia na Agricultura, Botucatu, v.28, n.2, p.109-114, 2013.

CIA, P.; BRON, I.U.; VALENTINI, S.R.T.; PIO, R.; CHAGAS, E.A. Atmosfera modificada e refrigeração para conservação pós-colheita de amora-preta. Bioscience Journal, Uberlândia, v.23, n.3, p.11-16, 2007.

DAMIANI, C.; VILAS BOAS, E.V.B.; PINTO, D.M.; RODRIGUES, L.J. Influência de diferentes temperaturas na manutenção da qualidade de pequi minimamente processado. Ciência e Agrotecnologia, Lavras, v.32, n.1, p.203-212, 2008.
JACQUES, A.C.; ZAMBIAZI, R.C. Fitoquímicos em amora-preta (Rubus spp). Semina: Ciências Agrárias, Londrina, v.32, n.1, p.245-260, 2011.

JOO, M.; LEWANDOWSKI, N.; AURAS, R.; HARTE J.; ALMENAR, E. Comparative shelf life study of blackberry fruit in bio-based and petroleum-based containers under retail storage conditions. Food Chemistry, Amsterdam, v.126, n.1 p.1734-1740, 2011.

JUNMATONG, C.; FAIYUE, B.; ROTARAYANONT, S.; UTHAIBUTRA, J.; BOONYAKIAT, D.; SAENGNIL, $\mathrm{K}$. Cold storage in salicylic acid increases enzymatic and non-enzymatic antioxidants of Nam Dok Mai No. 4 mango fruit. Science Asia, Nakhon Pathom, v.41, n.12, p.12-21, 2015.

KIVI, A.R. SARTIPNIA, N.; KHALKHALI, M.B. Effect of storage temperatures on antioxidant capacity and bioactive compounds in raspberry fruit. International Journal of Plant, Animal and Environmental Sciences, Hyderabad, v.4, n.3, p.343-349, 2014.

KRUPA, T.; TOMALA, K. Antioxidant capacity, anthocyanin content profile in 'Bluecrop' blueberry fruit. Vegetable Crops Research Bulletin, Warsaw, v.66, n.1, p.129-141, 2007.

MITCHAM, E.J.; CRISOSTO, C.H.; KADER, A.A. Bushberry, blackberry, blueberry, cranberry, raspberry: rocommendations for maintaining postharvest quality. Davis: University of California, 2007. Disponível em: $<$ http://postharvest.ucdavis.edu/PFfruits/Bushberries/>. Acesso em: 20 jun. 2016.

ODRIOZOLA-SERRANO, I.; OMS-OLIU G, SOLIVAFORTUNY R, MARTÍN-BELLOSO O. Effect highoxygen atmospheres on the antioxidante potential of fresh-cut tomatoes. Journal of Agricricultural and Food Chemistry, Washington, v.57, n.15, p.6603-6610, 2008.

PALHARINI, M.C.A.; FISCHER, I.H.; VEGIAN, M.R.C.; FILETI, M.S.; MONTES, S.M.N.M. Efeito da temperatura de armazenamento na conservação pós-colheita de amorapreta. Pesquisa Agropecuária Tropical, Goiânia, v.45, n. 4, p.413-419, 2015.

RUFINO, M do S.M.; ALVES, R.E.; BRITO, E. S. de; MORAIS, S.M. de; SAMPAIO, C. de G.; PEREZ-JIMENEZ, J.; SAURA-CALIXTO, F.D. Metodologia científica: determinação da atividade antioxidante total em frutas pela captura do radical livre ABTS. Fortaleza: Embrapa Agroindústria Tropical. 2007. 4p. (Comunicado Técnico, 128). 
SANDHYA, K.V.K. Modified atmosphere packaging of fresh produce: Current status and future needs. Food Science and Technology, Campinas, v.43, n.1, p.381392, 2010.

SCHAKER, P.D.C.; ANTONIOLLI, L.R. Aspectos econômicos e tecnológicos em pós-colheita de amoraspretas (Rubus spp). Revista Brasileira de Agrociência, Pelotas, v.15, n.1-4, p.11-15, 2009.

SHARMA, P.; SINGH, R.P. Evaluation of antioxidant activity in foods with special reference to TEAC method. American Journal of Food Technology, New York, v.8, n.1, p.83-101, 2013.

SOETHE, C. STEFFENS, C.A.; AMARANTE, C.V.T. do; MARTIN, M.S. de; BORTOLINI, A.J. Qualidade, compostos fenólicos e atividade antioxidante de amoraspretas 'Tupy' e 'Guarani' armazenadas a diferentes temperaturas. Pesquisa Agropecuária Brasileira, Brasília, v.51, n.8, p.950-957, 2016.

SOUZA, P.A.; MENEZES, J.B.; ALVES, R.E.; COSTA, F.B. da; SOUZA, G.L.F..M. Armazenamento refrigerado de melão Gália 'Solarking' sob atmosfera modificada. Caatinga, Mossoró, v.19, n.4, p.377-382, 2006.

STEFFENS, C.A.; BRACKMANN, A.; PINTO, J.A.V.; WEBER, A. Metodologia para determinação da permeabilidade de filmes poliméricos para uso em atmosfera modificada. Revista Brasileira de Armazenamento, Viçosa, v.34, n.2, p.87-94, 2009.
STEFFENS, C.A.; BRACKMANN, A.; PINTO, J.A.V.; EISERMANN, A.C. Taxa respiratória de frutas de clima temperado. Pesquisa Agropecuária Brasileira, Brasília, v.42, n.1, p.313-321, 2007.

VIZZOTTO, M.; RASEIRA, M. do C.B.; PEREIRA, M.C.; FETTER, M. da R. Teor de compostos fenólicos e atividade antioxidante em diferentes genótipos de amoreira-preta (Rubus sp.). Revista Brasileira de Fruticultura, Jaboticabal, v.34, n.3, p.853-858, 2012.

VIEITES, R. L. et al. Conservação do morango armazenado em atmosfera modificada. Semina: Ciências Agrárias, Londrina, v.27, n.2, p.243-252, 2006.

WANG, C.Y.; WANG, S.Y. Effect of storage temperatures on fruit quality of various cranberry cultivars. Acta Horticulturae, Wellington, n.810, v.1, p.853-862, 2009.

WEBER, A. et al. Atmosfera controlada para o armazenamento da maçã 'Maxi Gala'. Revista Ciência Agronômica, Fortaleza, v.44, n.2, p.294-301, 2013.

YANG, Y.; WANG, J.; XING, Z.; DAI, Y.; CHEN, M. Identification of phenolics in Chinese toon and analysis of their content changes during storage. Food Chemistry, Amsterdam, v.128, n.4, p.831-838, 2011. 